\title{
Bilateral Trades between Egypt and Malaysia: Issues and Opportunities for Further Development
}

\author{
Muhamad Muda $^{1}$, Siti Nurazira Daud ${ }^{1} \&$ Ibrahim Mohamed Ibrahim Eldeeb ${ }^{2}$ \\ ${ }^{1}$ Faculty of Economic and Muamalat, Universiti Sains Islam Malaysia, Nilai, Malaysia \\ ${ }^{2}$ Master candidate in Faculty of Economic and Muamalat, Universiti sains Islam Malaysia, Nilai, Malaysia \\ Correspondence: Ibrahim Mohamed Ibrahim Eldeeb, Batu Laban 8, Gombak, Malaysia. Tel: 601-111-880-528. \\ E-mail: ibrahimeldeeb1980@gmail.com
}

Received: November 12, 2016

Accepted: December 1, 2016

Online Published: December 14, 2016

doi:10.5539/ijef.v9n1p202

URL: http://dx.doi.org/10.5539/ijef.v9n1p202

\begin{abstract}
Egypt and Malaysia are both belong to the Organization of Islamic Conference (OIC), have a similar historical background that both have been under the British colony and have enjoyed independence at almost within the same period. However, trades between the two countries are relatively small, and if based on the socio-economic background the magnitude of trades between the two countries can be further improved. This paper traces the historical development of bilateral trade relationship between Egypt and Malaysia to understand the strength and weaknesses. The aim is to develop possible proposals for further enhancement of the relationship. The main objective of this paper is to investigate factors that may enhance integration and cooperation between Egypt and Malaysia. The research used qualitative analysis approach by looking at the trade sectors and volumes over the period of 2000-2012, based on the phenomenological case study method. It is found that Egypt and Malaysia enjoyed significant bilateral trade relations since the independence of Malaysia in 1957, especially in the fields of culture and education. Because of the appreciation of the Malaysian citizens to the Islamic-based education such as Islamic studies, medicine, and pharmacy particularly the world-renowned institution of Al-Azhar University, thousands of Malaysians have enrolled and graduated from this university and other related institutions. On the other hand, Malaysia is falling behind Argentina, Brazil and India regarding export to Egypt. However recently, Malaysia has been becoming popular for the Egyptian tourists. The paper explores a proposal for further improvement regarding bilateral trades based on Islamic approach.
\end{abstract}

Keywords: bilateral trade, Egypt, Malaysia, international trade, development economics

\section{Introduction}

The main purpose of pursuing the current study on trade relations between Malaysia and Egypt is to enhance the inter-trade between them to find a suitable way to the economic cooperation. This study is embarked and driven by some factors. First, there seems to be a desire to promote the economic relations between the two countries which are constantly developing. It is worth mentioning that the exports and imports between Malaysia and Egypt are very weak since 1960 through to 1979 . However, in the early 80s, there appears a new era in Malaysia towards the implementation of economic reform policies to improve the level of per capita income, which greatly forge the rise in its exports and imports. The results of this economic reform can be seen whereby the exports rise to its highest level in 2012. This perhaps also explains the commitment of the Malaysian government towards the implementation of the socio-economic plan in Vision 2020, which will move Malaysia to be among the developed countries. This plan has been drawn to the economic strategies policies to develop simple and medium projects toward achieving some important objectives such as enhancement of the ability competitiveness of Malaysian industries, improvement of industrial infrastructure. This plan also helps Malaysia in the Malaysian transformation industries and production of intermediate goods to the final products (Gomez, 1999).

\subsection{Background on Egypt and Malaysia}

Both countries starting from a similar point, both under British colonial and after independence they began the way of development. Furthermore, Egypt after obtaining independence on 23 June 1952, attempts to implement the socialist economic system by focusing on developing public sectors. The main characteristics of this era are furnished on knowledge in public universities although there is a lack of political freedom. Consequently, the Egyptian economic system is more centralized. In addition, Egypt was also constantly engaged in wars that 
might have disrupted its economic development. In 1978, Egyptian authorities signed a peace convention with Israel after the war that could pave the way for peace and improve concentration on economic development. Moreover, the slowdown in economic growth as a result of the wrong economic policy that led to corruption in each sector and increased the rate of unemployment (Hassan, 2001). The gross domestic product also (GDP) is equal to the total expenditures for all final goods and services produced within the country in a stipulated period. Egyptian GDP reflects big problems faced Egyptian economy. Egyptian GDP increased slowly until 2002. After that GDP increased dramatically from 2002 to 2012. Egyptian GDP reflects big problems faced Egyptian economy. It worth mention that a big gap in the Egyptian economic policies. In spite of the current situation of deficit trade balance and increased the unemployment problems and raised the rate of inflation and also deflation. And also the lack of political stability leads to economic instability in light of the lack of security. Furthermore, Policy of rising support for goods and services to fill the budget deficit and the instability of the market exchange rate.

Figure 1 explains the GDP since 1960 to 1979; it may seem the enhancement in the Egyptian domestic gross product since 1970 until 1979 because the GDP rapidly increased because focusing on other development aspects of the community. It worth to note that it may interpret developed all outputs of Egyptian economic sectors. Additionally, Egypt in this period has been promoted in several economic aspects. Unfortunately, Egypt lost their some its economic power because of preoccupation with some political issues such as the war with Israel since 1960 until 1973. However, the most important effects of revolution are the escape of foreign investments. It should be noted that the instability of the political situation leads to a more economic crisis in Egypt. Some of the employees lost their jobs in the last decade, and some factories have been closed, and more social factors have been raised. Egypt in this period has been promoted in several economic aspects. Unfortunately, Egypt lost they're some its economic power because of preoccupation with some political issues such as the war with Israel since 1960 until 1973. However, the most important effects of revolution are the escape of foreign investments. It should be noted that the instability of the political situation leads to a more economic crisis in Egypt. Some of the employees lost their jobs in the last decade, and some factories have been closed, and more social factors have been raised. It has been seen obvious that all of exports and imports do not reach to the situation that reduced the deficit trade balance. Moreover, Egyptian import volumes reached US $\$ 43.98$ billion in 2009, a 24 percent rise from the previous year's level. It has been clear that a surplus import. Egypt has had a negative balance of trade (trade deficit) since the 1980s. Also, the indicator of import and export has been increased after the financial crisis since 2008 to 2010. During this time Malaysia starts the way of development since independence in 1957. At this time since 30 years, Prime Minister Mahathir Mohamed begins to improve industry sector.

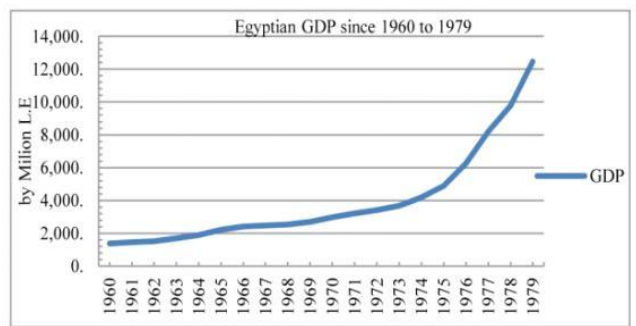

Figure 1. Egyptian gross domestic products since 1960 to 1979 Source: CAPMAS (2014)

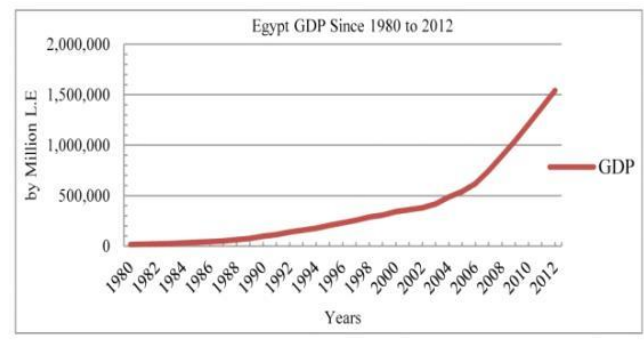

Figure 2. Egyptian gross domestic products since 1980 to 2012 Source: CAPMAS (2014).

Figure 2 reveals the gross domestic products since 1960 to 2012. It should be pointed out that the stability of gross domestic product since 1960 to 2012. It should be noted that during this time in Malaysia struggle to improve the industrial sector. In addition, Figure 2 interprets the transformation from agriculture community to the industrial community by the successful economic policy (Porter, 2000). This figure also reveals the way that Malaysia enhanced the manufacturing development. It may promote the cluster-based concept by improving some relations that can organize production process and between some other activities (Ketels, 2003). Figure 2 also reveals the GDP in Malaysia recorded the highest point in 1997. It should be noted that the GDP increased dramatically. It also refers to economic improvement. The diagram also emphasizes that the Malaysian economy struggles to achieve the target vision 2020.The diagram also reflects the successful economic approach as discovering the basis of the pursuit of successful economic policies toward the target 2020. However, the big significant challenge facing the country is raising gap between the actual growth rate and the projected growth rate required to reach the targets to shift the country from a middle-income economy to a high-income economy by 2020. Moreover, Malaysia going very fast to another development stage by improving the heavy industrial 
sector. Also, Malaysia also developed the education system and open the way for utilities from exchange expertise. Nevertheless, both countries have similar Islamic vision about integration under the unity of Muslims (Daugbjerg, 2015). Also, the historical relations between both countries encourage to strength this relation by implement more agreements especially after signed and ratified a full agreement in 2013. Both Egypt and Malaysia have embraced economic policies that are different from each country, and some of its objectives follow the economic system whereby others have embraced a market economy and others a mixture of both. Both countries followed different versions of economic policies, whether for industrial goods, agricultural or services. Moreover, these countries have not benefited regarding industrial raw materials or competitiveness in the different industries or agricultural commodities; it is a result of these policies' deepening dependency to the outside market.

\subsection{Bilateral Trade between Egypt and Malaysia}

In fact, the simplest form of economic integration which provides the free trade between two or more countries (Guan, 2005). According to the simplest principle of economic integration theory among two countries, the relation between Malaysia and Egypt is one of the most important bilateral relationships in Southeast Asia and North Africa. It is one of the best examples to enhance bilateral trade between two countries. Harun (2009) reveals that the balance of trade is inclined towards Malaysia due to the remarkable activity of Malaysian businessmen to explore the Egyptian markets and the opportunities of exporting to Egypt, in addition to the existence of a "Malaysian National Trade Promotion Agency" office in Cairo to support Malaysian businessmen. Both Malaysia and Egypt have many common characteristic and traits; these include common frames of reference in vision, culture, and religion. Malaysia is one of the most important Islamic countries that were able to go beyond the defaults and proceed to development in various fields of life and living conditions ranging from the economy through education, technology and the end of the health and culture. In addition, Egypt also is the largest Muslim country in the Middle East and it's achieved a good position because of high levels of trade with Islamic countries, which leads to enhancing and promote trade volume for a move towards economic integration between two countries. Currently, Egypt has a lot of educational relation with Malaysia more clearly than ever before. Egypt and Malaysia share a lot of views and at the multilateral level, as they continue to be active in the OIC, NAM, and the UN which is useful in promoting co-operation between both countries, as well as the other member states. This strong cooperation contributes to finding solutions to global problems and in establishing common ground rules that will guide the best conduct of international relations. Originally, the balance of trade is inclined towards Malaysia due to the remarkable activity of Malaysian businessmen to explore the Egyptian markets and the opportunities of exporting to Egypt, in addition to the existence of a "Malaysian National Trade Promotion Agency" office in Cairo to support Malaysian businessmen. In fact, both Malaysia and Egypt need to devote efforts to start a free movement of goods, services, and labor to achieve the cooperation and integration markets between them. It also provides free movement of production factors allows optimum allocation of labor and capital. Moreover, cooperation and integration between Egypt and Malaysia led to overcome the problem of entrepreneurs to shift their capital from places of low return to other high return places. However, capital movements the willingness to integrate is less obvious because cooperation and integration may lessen the effectiveness of critical macroeconomic instruments. Confirming the importance of policy cooperation and integration and taking into account the role of the state in enhancing economic welfare by correcting imperfection of markets and in realizing some political objectives such as an equitable income distribution. Furthermore, if objectives of two governments are inconsistent, the policy of one country will frustrate that of the other. Consequently, policy cooperation and integration may bring the economic benefit that leads to recovery of effectiveness in policy making. In addition, the transaction cost between governments increases with the increase in the numbers of negotiators and the diversity of paradigms in which they work.

There seem to be a need for joint investments and to promote the economic relations between the two countries which are constantly developing. It is worth mentioning that the exports and imports between Malaysia and Egypt are modest and very simple since 1960 and until 1979.However, in the early80s there a new era in Malaysia towards the implementation of economic reform policies and improve the level of per capita income, which greatly affected the rise in exports and imports from Malaysia. This can be seen up to its highest level in 2012. It also explains the commitment of the Malaysian government towards the implementation of the plan in 2020, which will move Malaysia to be among the developed countries.

\section{Literature Review}

The mechanism and process of economic integration have been the focus of many scholars in this area of which we will look at in this section. However, for a startup in the economic integration effort as this study is investigating, we will also look at the definition of what integration means. In addition, what is equally important 
is to understand why countries would want to integrate, what benefits they will reap as the result of the outcome. In lights of the recent "Brexit" incident which could be seen as reverse integration, this has raised some lights into whether the benefits expected from integration could be realistic. However, in our view, that will be a major issue to consider and is outside the scope of this study. At this moment we will focus on the conventional factors that motivate countries, particularly the developing ones like Malaysia and Egypt, to economically integrate. According to Machlup (1977), integration is the process of combining separate economies into one larger economic region. Machlup and Staley (1977) indicates that integration is concerned with the utilization of all potential opportunities and efficient division of labor. Umo (2002) on the other hand, refers to integration as the unification of neighboring countries working within a framework to promote free movement of goods, services, and factors of production to coordinate and harmonize their policies. Two factors have been identified that facilitate the regional economic integration, firstly, the neighboring countries have common history and interests and may be more willing to coordinate. Secondly, countries who are not neighbors (integration agreements) but if their ideologies are similar. According to Madyo (2009), economic integration is a process that includes procedures led to removing discrimination among different countries. One of the most notable trends in the global economy in recent years has been an accelerated movement toward regional economic integration such as ASEAN, AFTA, NAFTA, APEC, and EU. Linking countries together making them more dependent on each other by entering into regional agreements, group countries aim to reduce trade barriers more rapidly than can be achieved. All countries can benefit if each country specializes in the production of those goods it can produce best and satisfy their other wants and needs by trading for them. Balassa (1961) emphasized that there are a wide range and various reasons why countries accepted the agreement of economic integration. The economic cooperation and integration between Egypt and Malaysia would lead to solving the economic problems in both countries by using Islamic concepts to enhance and improve the bilateral trade movements. Furthermore, improve economic cooperation and integration between Egypt and Malaysia by using Islamic concepts taking into account the global economic condition, diversify and create new opportunities in trade relations, enhance participation in decision-making at international level, and improve standards of living. In the last few years, Malaysia and Egypt have adopted many common views on the international level and in the multilateral forums, which they are members of the OIC organization and the non-aligned movement organization and the UN, which support cooperation between two countries. Moreover, contributing to finding solutions to global problems and to establish common rules to support economic relationship, Egypt, and Malaysia shares the views on global issues such as human rights and environmental issues, and refugee issues. The desire to strengthen cooperation led both countries to try to use new economic policies through signing and ratifying bilateral trade agreements since 2013 (Egypt Embassy, 2014).

Considering the importance of promoting the relationship between Malaysia and Egypt and putting in mind the unity of Muslim countries, there are two valuable concepts; Firstly, to encourage the free movement of goods, services, and factors of production between the member's state. Secondly, to increase cooperation in the field of fiscal and monetary policy that also follows the liberalization of trade between the members' states to activate preferential trade agreements, which will lead to the reduction of trade barriers between each. Egypt and Malaysia desire to improve the bilateral trade since Egyptian revolution in 25th January 2011 to alleviate the effects of negative political that happened in Egypt other (El-Said, 2014). However, economic integration offers additional opportunities to share risks and have smooth consumption temporally (Kalemli Ozcan, 2001). Another aspect that has been the focus of integration literature is on its mechanism. In this paper, we will also explore how Egypt and Malaysia should place their attention in the process of integration. Hitiris (1991) mentions that economic integration among developed countries concentrate on the changing of trade pattern as undeveloped countries seek economic agglomeration to enhance development in making essential structural production to be able to generate a sizeable trade. Consequently, Regional Trade Agreements form a key part of the institutional structure of the world economy. For this kind of agreement, there is no general reduction on internal tariffs without a common external tariff. Tariffs between the members of the agreement are reduced (or eliminated) only for some goods or services, sometimes unilaterally (Ahmed, 1970). Viner (1950) focused on the impact of the formation of the Customs Union on the production. This theory has been developed by Lipsey (1960) and Meade (1953). The Customs Union in literature occurs when two or more countries agree to eliminate tariffs between themselves and set a common external tariff on imports from the rest of the world. Viner (1950) also used this analysis of neoclassical theory in foreign trade and uses religious duties such as full competition, the stability of production costs and lack of transportation costs. However, there is another approach in customs union theory which does not lay emphasis on welfare improving effects of liberalization, but views economic integration as a means for a continuation of national import of substitutions policies on a wider regional level (Corden, 1972). The Customs Union avoids the problem of developing complicated rules of origin but introduces 
the problem of policy coordination. With a customs union, two countries or more must be able to agree on tariff percentages across many different import industries. Lipsey (1960) emphasizes in terms of trade of the member states. Viner focused on short-term effects. Viner (1950) also used this analysis of neoclassical theory in foreign trade and uses religious duties such as full competition, the stability of production costs and lack of transportation costs. Viner (1950) referred on the improvement of transportation costs, and he also assumes that the importance of proximity as a factor in granting preferential tariff. Balassa (1960) referred to the proximity between the member states of the Customs Union has raised the positive economic integration. Egypt and Malaysia share a common objective to improve multilateral trade level as they continue to be active in the OIC, NAM, and the UN. This is useful in promoting co-operation between both countries. This strong desire to cooperate contributes to finding solutions to trade problem and in establishing common ground rules that will guide the best conduct of international relations. Initially, the balance of trade is inclined towards Malaysia due to the remarkable activity of Malaysian businessmen to explore the Egyptian markets and the opportunities of exporting to Egypt. In addition, this success is also assisted by the existence of Malaysian National Trade Promotion Agency office in Cairo to support the Malaysian businessmen (Harun, 2009). Maximum integration is permitted between the economies of the member states. Full economic integration is through the emergence of an immediate nature organizations or supranational. It had the authority to put monetary and fiscal policies, trade and implemented without reference to the member states, and this is what distinguishes this power under full economic integration (Twana, 2010).

\section{Methodology}

The qualitative research allows to deeply understanding the phenomenon of weakness of bilateral trade between Egypt and Malaysia. It has been clearly obvious that using qualitative research definitely provide a full discussion of this type of case study between both countries. The main task of using qualitative approach is to deeply understand; in this case, the Islamic view that existed in pre and post-Islam integration. In fact, by using a qualitative approach, the reader can take the economic practices from both conventional and Islamic eras to provide the best solution to the phenomenon of weakness of bilateral trade between both countries. In turn, a process can be determined for both countries in bilateral relations to undergo to achieve a successful economic relationship. Phenomenology theory enables researchers to generate theories that offer an explanation of behavior, creation of a new theory, application in worldly practices, and providing a general perspective. Regarding behaviourism, it provides clear hypotheses that are ideal for further research (Denzin, 2009). Freebody (2004) lists the criteria of a case study which is the framework for this study. Therefore, it allows the exploration of different perspectives to achieve their goals (Lindgren \& Kehoe, 1981 cited in Vaughn et al., 1986; Henry, 2008). It should be noted that the phenomenological case study approach is a qualitative research to explain more details about the phenomenology of the weakness of bilateral trade between both countries (Henry, 2008).

\section{Discussion}

Figure 1 illustrates the movement of goods and services in Malaysia from 1980 to 2012. It should be noted that the movement of exports and imports slightly increased in 1983 and sharply increased from 1986. The Malaysian export consists mainly of agriculture, manufacturing and mining goods. The economic indicator shows that the most exported good is Palm oil (45 percent), optical \& scientific equipment (17 percent) and non-Metallic Mineral products (11 percent). Furthermore, the Malaysian import indicators show that textiles, clothing \& footwear is $3 \%$ of the total Malaysian imports. Moreover, this may explain the implementation of the strategic development plan since 1980 to 2012. Although there is fluctuation in the trend of Malaysian import and export, however, the movement of import and export has improved since 2000 because of the implementation of some economic recovery policies.

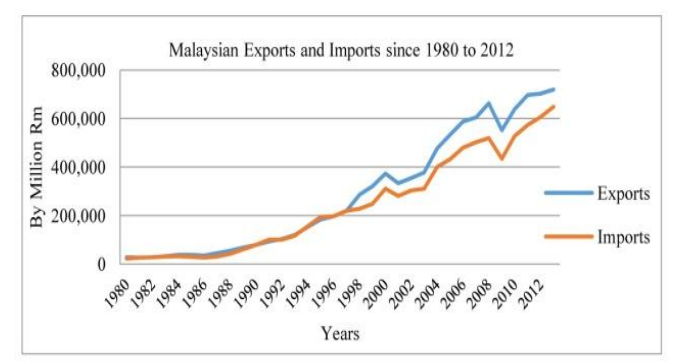

Figure 3. Malaysian exports and imports since 1980 to 2012 Sourse. MITI (2014).

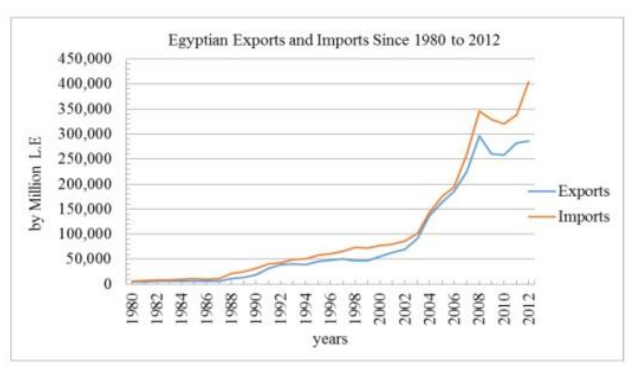

Figure 4. Egyptian exports and imports since 1980 to 2012 Sourse. CAPMAS (2014). 
Figure 3 shows a rapid increase in exports and imports and successful policies up till 1999. It also reflects the trade movements in goods and services. The figure also reveals the significant performance of goods and services in the last decade. In addition, exports and imports have been promoted since last ten years. Moreover, assessment of the movement of exports and imports in last ten years led to putting economic policies as a model for other Muslim countries particularly Egypt. The fluctuation of imports and exports since 2008 to 2010 illustrated the reasons for the decline of both. However, the economic reforms by Malaysian government lead to rapid growth and refer to the structural change in equality. In addition, the government has sought through an economic model of 2010 to put the economy back on the growth for Malaysia to be in a high degree income country by 2020. Furthermore, it shows the trade policy and commitment of consequences of liberalized trade.

Figure 4 reveals the movements of exports and imports of goods and services since 1980 to 2012. It has been seen obvious that all of exports and imports do not reach to the situation that reduced the deficit trade balance. Moreover, Egyptian import volumes reached US $\$ 43.98$ billion in 2009, a 24 percent rise from the previous year's level. It has been clear that a surplus import. Egypt has had a negative balance of trade (trade deficit) since the 1980s. In addition, the indicator of import and export has been increased after the financial crisis since 2008 to 2010. Since the 1980s, the government has pioneered several economic reforms through foreign donor aid. However, it has measurable benefits of these economic reforms. The economy is highly dependent on oil exports, which are its major source of foreign income together with tourism receipts and US financial and military aid. It has to import most of its food, other commodities, and equipment since both its agricultural and industrial sectors are not well-developed. Additionally, the problem in Export and import since 1980 to 2002 is not achieving the suitable level and not achieve the required level of international trade. Since the 1980s, the government has pioneered several economic reforms through foreign donor aid. However, it has measurable benefits of these economic reforms. The economy is highly dependent on oil exports, which are its major source of foreign income together with tourism receipts and US financial and military aid. It has to import most of its food, other commodities, and equipment since both its agricultural and industrial sectors are not well-developed. Additionally, the problem in Export and import since 1980 to 2002 is not achieving the suitable level and not achieve the required level of international trade.

Table 1. Egyptian Trade Exchanges with some of the non-OIC member under trade partner countries group (2008-2011) by million L.E

\begin{tabular}{|c|c|c|c|c|c|c|c|c|c|c|c|c|c|c|c|c|}
\hline \multirow[b]{2}{*}{ Countries } & \multicolumn{3}{|c|}{2008} & \multicolumn{5}{|c|}{2009} & \multicolumn{3}{|c|}{2010} & \multicolumn{5}{|c|}{2011} \\
\hline & Exports & Imports & $\begin{array}{c}\text { Trade } \\
\text { balance }\end{array}$ & $\begin{array}{c}\text { Trade } \\
\text { Volume }\end{array}$ & Exports & Imports & $\begin{array}{c}\text { Trade } \\
\text { balance }\end{array}$ & $\begin{array}{c}\text { Trade } \\
\text { Volume }\end{array}$ & rts & Imports & $\begin{array}{c}\text { Trade } \\
\text { balance }\end{array}$ & $\begin{array}{c}\text { Trade } \\
\text { Volume }\end{array}$ & rts & Imports & $\begin{array}{c}\text { Trade } \\
\text { balance }\end{array}$ & $\begin{array}{c}\text { Trade } \\
\text { Volume }\end{array}$ \\
\hline Argentina & 595.6 & 5532.8 & -4937.3 & 6128.4 & 124.8 & 2556 & -2431.2 & 2680.8 & 45 & 10845.9 & -10800.9 & 10890.9 & 141.3 & 5031.8 & -4890.5 & 5173.1 \\
\hline Brazil & 681.3 & 7873.2 & -7191.9 & 8554.5 & 250 & 6870 & -6620 & 7120 & 1615.1 & 14335.6 & -12720.5 & 15950.7 & 1194.1 & 9835.2 & -8641.1 & 11029.3 \\
\hline Chile & 29.7 & 361.7 & -332 & 391.4 & 1.3 & 122 & -120.7 & 123.3 & 236.8 & 184.3 & 52.5 & 421.1 & 405 & 78 & 327 & 483 \\
\hline Colombia & 33.8 & 32.2 & 1.6 & 66 & 27.5 & 12 & 15.5 & 39.5 & 83.5 & 91.9 & -8.4 & 175.4 & 35.5 & 97.7 & -62.2 & 133.2 \\
\hline India & 9045.6 & 9586.6 & -541 & 18632.2 & 8095 & 6998 & 1097 & 15093 & 13414 & 9738.9 & 3675.1 & 23152.9 & 7188.4 & 8830.1 & -1641.7 & 16018.5 \\
\hline Jamaica & 2 & ------ & 2 & 2.0 & 1.1 & ------- & 1.1 & 1.1 & 1.3 & -------- & 1.3 & 1.3 & 1.1 & ------- & 1.1 & 1.1 \\
\hline Kenya & 625.8 & 1097.7 & -471.9 & 1723.5 & 646.6 & 1155 & -508.4 & 1801.6 & 1348 & 2008.4 & -660.4 & 3356.4 & 1418.1 & 1168.6 & 249.5 & 2586.7 \\
\hline Mexico & 1519.3 & 593.3 & 926.1 & 2112.6 & 362.2 & 401 & -38.8 & 763.2 & 149.6 & 407.8 & -258.2 & 557.4 & 204.6 & 473 & -268.4 & 677.6 \\
\hline Peru & 14.2 & 34.8 & -20.5 & 49 & 10.2 & 17 & -6.8 & 27.2 & 14.5 & 58.2 & -43.7 & 72.7 & 19 & 20.4 & -1.4 & 39.4 \\
\hline Srilanka & 178 & 73.7 & 104.2 & 251.7 & 87.6 & 82 & 5.6 & 169.6 & 77.6 & 128.9 & -51.3 & 206.5 & 89.1 & 85 & 4.1 & 174.1 \\
\hline Venezuela & 22.7 & 456.5 & -433.8 & 479.2 & 14.7 & 300 & -285.3 & 314.7 & 35.3 & 20.7 & 14.6 & 56 & 15.1 & 272.5 & -257.4 & 287.6 \\
\hline Zimbabwe & 6.6 & 2.7 & 4 & 9.3 & 17.2 & 2 & 15.2 & 19.2 & 67.2 & 5.7 & 61.5 & 72.9 & 76.9 & 95.5 & -18.6 & 172.4 \\
\hline
\end{tabular}

Source: CAPMAS (2014).

Table 1 shows the trade volume and trade balance between Egypt and some non-OIC countries under fifteen group from 2008 until 2011. It should be mentioned that all these countries are under fifteenth countries group. It has been obvious that the trade volume between some of these countries is much higher than the trade volume between Egypt and Malaysia such as India, Mexico, Brazil, and Argentina. Consequently, the Islamic perspective could be a good motive to enhance and promote the bilateral trade between Egypt and Malaysia (CAPMAS, 2014). 
Table 2. Egyptian trade exchange with some of OIC member trade partner countries group (2008-2011) by million L.E

\begin{tabular}{|c|c|c|c|c|c|c|c|c|c|c|c|c|}
\hline \multirow[b]{2}{*}{ Countries } & \multicolumn{3}{|c|}{2008} & \multicolumn{3}{|c|}{2009} & \multicolumn{3}{|c|}{2010} & \multicolumn{3}{|c|}{2011} \\
\hline & Exports & Imports & $\begin{array}{c}\text { Trade } \\
\text { balance }\end{array}$ & Exports & Imports & $\begin{array}{c}\text { Trade } \\
\text { balance }\end{array}$ & Exports & Imports & $\begin{array}{c}\text { Trade } \\
\text { balance }\end{array}$ & Exports & Imports & $\begin{array}{c}\text { Trade } \\
\text { balance }\end{array}$ \\
\hline Algeria & 1031.70 & 2697.40 & -1665.70 & 2119.4 & 2101 & 18.40 & 2306.7 & 4079 & -1772.30 & 1510.9 & 2338.2 & -827.30 \\
\hline Iran & 332.60 & 185.10 & 147.50 & 486.70 & 187 & 299.70 & 556 & 207.10 & 348.90 & 790.30 & 246.70 & 543.60 \\
\hline Indonesia & 400.20 & 4142.60 & -3742.30 & 532.10 & 2965 & -2432.9 & 549.30 & 5356.4 & -4807.10 & 606.80 & 3017.1 & -2410.30 \\
\hline Malaysia & 199.50 & 3052.40 & -2852.80 & 147 & 2882 & -2735 & 738.40 & 4572.5 & -3834.10 & 1177 & 4444.8 & -3267.80 \\
\hline Nigeria & 2551.10 & 0.8 & 2550.30 & 505.40 & 4 & 501.40 & 671.30 & 9.30 & 662 & 832.30 & 6.80 & 825.50 \\
\hline Senegal & 132.40 & 8.20 & 124.30 & 125 & 5 & 120 & 139.60 & 5.60 & 134 & 178 & 7 & 171 \\
\hline
\end{tabular}

Source: CAPMAS (2014).

Table 2 illustrates the bilateral trade between Egypt and some of the OIC countries under trade partners group from 2008 until 2011. It should be mentioned that the trade volume and trade balance between Egypt and other countries is much higher than the trade volume between Egypt and Malaysia such as Indonesia. It can be clearly seen that OIC play an important role to collect between these countries to enhance trade together to alleviate poverty. It worth mentioning that the fluctuation of trade volume shows the weakness of movement in goods, services, and labors, it may reflect the deep gap problem in cooperation and integration policy among these countries (CAPMAS, 2014).

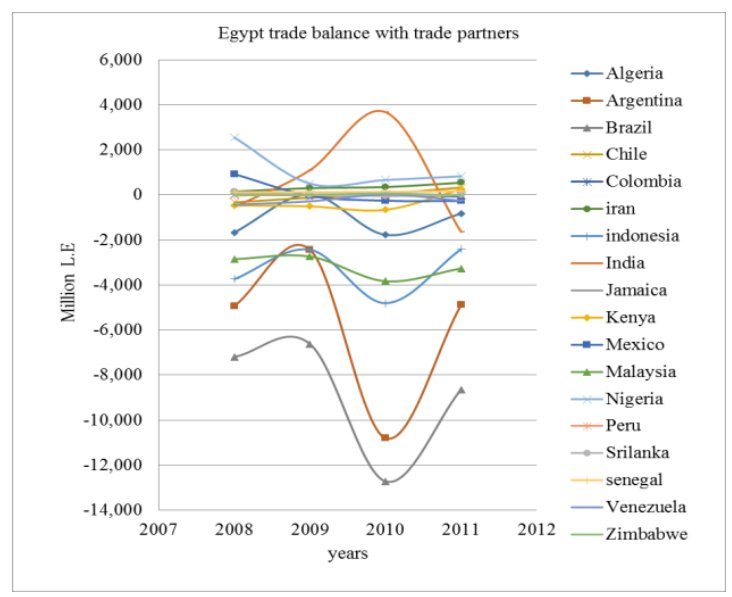

Figure 5. Egypt trade balance with trade partners since 2008 to 2011 Source: CAPMAS (2014).

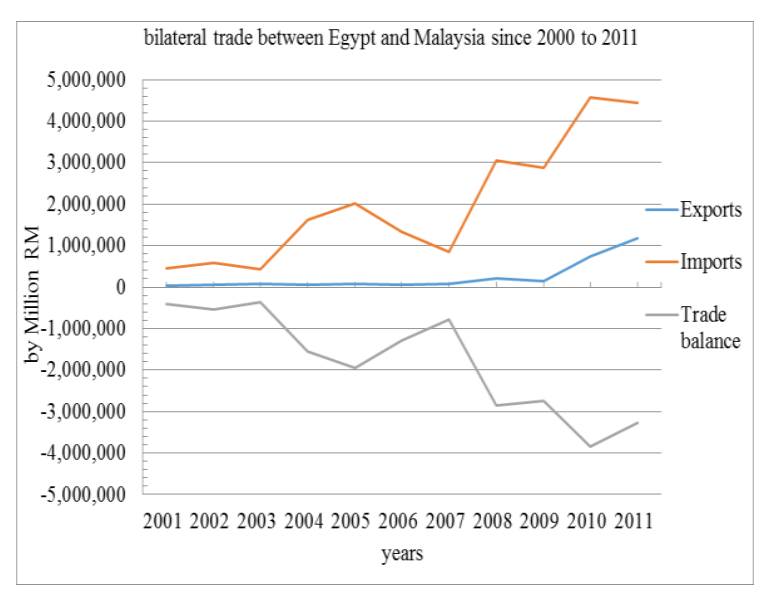

Figure 6. Bilateral trade between Egypt and Malaysia since (2001-2011) Source: CAPMAS (2014).

Figure 5 reveals that Egypt has a deep problem in bilateral trade with fifteenth countries. It has been obvious that the bilateral trade increased only in natural resources. It also shows the deficit of trade volume in bilateral trade between Egypt and most of the fifteenth countries group. The best example here is the bilateral trade with India. Only if we promote the bilateral trade between Egypt and Malaysia such as India, we will undoubtedly be gain the ultimate benefits of what provides us toward enhancing bilateral trade-economic.

Line chart 6 reveals the bilateral trade between Egypt and Malaysia since 2001 until 2011. It worth be noted that the trade balance was slumped to increasing the gap of deficit among export and import. Consequently, the chart illustrates unbalanced movements between imports and exports especially from 2005 to 2011. It can be clearly seen that imports remained stable from 2001 to 2007. In contrast, it should be mentioned that imports line dramatic rise since 2007 to 2011.

Table 3. The trade volume between Egypt and Malaysia since 2001 to 2011 million L.E

\begin{tabular}{cccc}
\hline Years & Exports & Imports & Trade balance \\
2001 & 38727 & 445212 & -406485 \\
2002 & 50883 & 589021 & -538138 \\
2003 & 81086 & 434983 & -353897 \\
2004 & 65210 & 1623795 & -1558585 \\
2005 & 78882 & 2020274 & -1941392 \\
2006 & 52352 & 1339656 & 855041 \\
\hline
\end{tabular}




\begin{tabular}{cccc}
\hline 2007 & 77073 & 855041 & -777968 \\
2008 & 199500 & 3052400 & -2852900 \\
2009 & 147000 & 2882000 & -2735000 \\
2010 & 738400 & 4572500 & -3834100 \\
2011 & 1177000 & 4444800 & -3267800 \\
\hline
\end{tabular}

Source: CAPMAS (2014).

It can be clearly seen that the volume of Trade between the two countries does not rise to the level of distinguished relations that combine between Egypt and Malaysia. The clear deficit has been shown in the movement of exports and imports between these countries. The previous table also reveals the fluctuation of trade volume between Egypt and Malaysia and the lowest level of cooperation between two countries. In fact, they cooperate in a few products such as liquefied natural gas projects, palm oil, wood, electrical appliances, computers, cocoa, wheel tires, detergents, and copper. Without forgetting the main concept of Islamic unity that tends to enhance and promote the cooperation and integration between Muslim countries in general, especially countries under OIC organization such as Egypt and Malaysia and without forgetting the importance of these two countries in Asia and Africa as well. This research focuses on the current scenario of bilateral trade between Egypt and Malaysia. It should be noted that both countries have significant criteria and they struggle to achieve their goals by increase economic activity. Additionally, both countries also have a good geographical position in the southeast of Asia and the north of Africa, especially in Arab countries. Cooperation and economic integration between Egypt and Malaysia have its advantages, as it prepares for the two countries expanded market, but since the existence of a common market between Egypt and Malaysia, it is understood that the industry needs to have a wide market to be economically produced.The cooperation and economic integration between Egypt and Malaysia derive its legitimacy from the call of Islam to the Muslims of cooperation and brotherhood and unity even in the areas of economic activity, and economic aspects of life. It is agreed among scholars, is free trade between Islamic regions, which means prevent the imposition of customs duties on Muslims trade where there is justification for that, as a Muslim capital will be subject to the commitment of essential financial, zakat and the imposition of the toll or tariff means repetition of the financial obligation for a Muslim capital.

\section{References}

Balassa, B. (1961). The theory of economic integration: Limits and Prospects (p. 36). Allen and Unwin, London.

Convery, I., Soane, I., Dutson, T., \& Shaw, H. (2010). Mainstreaming LEADER Delivery of the RDR in Cumbria: An Interpretative Phenomenological Analysis. Sociologia Ruralis, 50(4), 370-391. https://doi.org/10.1111/j.1467-9523.2010.00519.x

Cooper, C. A., \& Massell, B. F. (1965). A New Look At Customs Union Theory. The Economic Journal, 75(300). https://doi.org/10.2307/2229672

Corden, W. M. (1972). Economies of Scale and Customs Union Theory. The Journal of Political Economy, 80(3). https://doi.org/10.1086/259899

Daugbjerg, C., \& Swinbank, A. (2015). Globalization and new policy concerns: The WTO and the EU's sustainability criteria for biofuels. Journal of European public policy, 22(3), 429-446. https://doi.org/10.1080/13501763.2014.927520

Denzin, N. K., \& Lincoln, Y. S. (2009). Qualitative research. Yogyakarta: PustakaPelajar.

El-Said, H., \& Harrigan, J. (2014). Economic reform, social welfare, and instability: Jordan, Egypt, Morocco, and Tunisia, 1983-2004. The Middle East Journal, 68(1), 99-121. https://doi.org/10.3751/68.1.15

Freebody, P. (2004). Qualitative Research in Education-Interaction and Practice. London: Sage Publishers.

Gomez, E. T., \& Jomo, K. S. (1999). Malaysia's Political Economy, Politics, Patronage and Profits (pp. 173-174). Cambridge University Press.

Guan, B. T. C. (2005). ASEAN's Regional Integration Challenge: The ASEAN Process. The Copenhagen Journal of Asian Studies, 20, 70-94.

Harun, R. (2009). In Pursuit Of National Interest: Change And Continuity In Malaysia's Foreign Policy Towards The Middle East. Jurnal Antarabangsa Kajian Asia Barat, 1, 23

Hasaan, K. M. (2001). An Empirical Investigation of Economic Cooperation Among OIC Member Countries. Working Paper 0212, ERF Working Paper Series, Egypt.

Henry, A., Casserly, A., Coady, M. \& Marshall, H. (2008). A Phenomenological Case Study Exploring Different 
Perspectives on Inclusion within One Post-Primary School.in the North West of Ireland. Sligo, Ireland: St. Angela's College and NUI Galway.

Husin, T. S. (2002). Forging An Economic Integration: The Case Of ASEAN (Order No. 3052488, Argosy University/Sarasota). Proquest Dissertations and Theses (pp. 155-155).

Ketels, C. (2003). The Development of the cluster concept-present experiences and further developments. In NRW conference on clusters, Duisburg, Germany (Vol. 5).

Machlup, F. (1977). A History of Thought on Economic Integration (p. 50). New York: Columbia University Press. https://doi.org/10.1007/978-1-349-03171-9

Madyo, M. R. (2009). The importance of regional economic integration in Africa (p. 125). University of South Africa.

Molle, W. (2001). The Economics of European Integration Theory (4th ed., p. 32).

Molle, W. (2006). The economics of European integration: Theory, practice, policy (p. 45). Ashgate Publishing, Ltd.

Pardo, S. (2004). Europe of Many Circles: European Neighbourhood Policy. Geopolitics, 9(3), 731-737. https://doi.org/10.1080/14650040490478756

Porter, M. E., Takeuchi, H., \& Sakakibara, M. (2000). Can Japan Compete? Basic Books.

Salvatore, D. (1995). International Economics (5th ed., p. 300). Prentice Hall International, Inc., Englewood Cliffs, New Jersey, U.S.A.

Todaro, M. P. (2000). Economic Development (7th ed., p. 130). Pearson Education Limited, English.

Twana, S. (2010). Topical Problems of European Integration Process (Dissertation Thesis, p. 9). University Of Pardubice.

Vaitsos, C. V. (1978). Crisis in Regional Economic Cooperation (Integration) Among Developing Countries: A Survey. World Development, 6(6), 719-769. https://doi.org/10.1016/0305-750X(78)90041-4

Van Bavel, B., Campopiano, M., \& Dijkman, J. (2014). Factor markets in early Islamic Iraq, c. 600-1100 AD. Journal of the Economic and Social History of the Orient, 57(2), 262-289. https://doi.org/10.1163/15685209-12341349

Viner, J. (1950). The Customs Union Issue. New York: Carnegie Endowment for International Peace.

Williams, T. N. (2002). EU- NATO Cooperation in the Fight against Islamic Fundamentalist Terrorism. In J. Krause, A. Wenger, \& L. Watanabe (Eds.), Unravelling the European Security And Defence Policy Conundrum (pp. 189-204). Zurich: Peter Lang Publishers.

Website:

http://studies.alarabiya.net/hot-issues/2014

http://www.Capmas. gov.eg/2014

http://www.Icci-Oic.org/2014

http://www.Icdt.org. 2014

http://www.mfa.gov.eg/english/Pages/default.aspx/2014

http://www.miti.gov.My/2014

http://www.Oic-Oic.Org/2014

http://www.Worldbank.Org/2014

\section{Copyrights}

Copyright for this article is retained by the author(s), with first publication rights granted to the journal.

This is an open-access article distributed under the terms and conditions of the Creative Commons Attribution license (http://creativecommons.org/licenses/by/4.0/). 